\title{
The Effect of a Metacognition-based Instructional Practice on the Metacognitive Awareness of the Prospective Teachersi
}

\author{
Burcu Duman*, Çetin Semerci \\ Faculty of Education, Bartın University, Turkey
}

Copyright $\mathrm{O} 2019$ by authors, all rights reserved. Authors agree that this article remains permanently open access under the terms of the Creative Commons Attribution License 4.0 International License

\begin{abstract}
The purpose of the study is to identify the effect of a metacognition-based instructional practice on metacognitive awareness of prospective teachers. The study has been carried out through "Pre-test - Post-test Control Group Model" which is one of the models in experimental design. The study group consists of 44 prospective teachers having education at Department of Turkish Language Education at a State University selected for either experimental or control group according to the result of the cluster analysis. For the experimental group, a metacognitive-based instructional practice has been carried out. On the other hand, current education schedule has been followed for the control group. "Metacognitive Awareness Scale" has been used as a data collection tool. According to the research results, metacognitive awareness scores are significantly different at some sub-dimensions in favor of the experimental group. A metacognition-based instructional practice has positively affected the improvement of the prospective teachers. It is suggested that future studies should be carried out by including all courses at the faculties of education.
\end{abstract}

Keywords Metacognition, Metacognitive Awareness, Prospective Teacher

\section{Introduction}

How human mind works, how thinking process is formed, how learning happens and how knowledge is perceived are the subjects mostly researched in the science world. While metacognitive theories particularly attract attention at clarifying how human mind works, it has roots in various theories such as the conditioning related to how learning happens, data processing, social cognitive theory and constructive understanding. How individuals get the knowledge becomes crucial rather than what knowledge they get during the teaching process. Therefore, the paradigm of the new century is whether individuals know the ways of "learning how to learn" rather than what the individuals learn [1]. The contemporary (modern) orientations at the education focus more on improving the metacognition through a student-centered and constructive understanding rather than a teacher-centered traditional approach [2].

Metacognition has been first used in the field of education by Flavell in 1971 in order to express the individual's self-control over his/ her learning and memorizing processes $[3,4]$. Metacognition is based on the premise that "when the individual understands how his/her own metacognitive processes continue, he/she can take these processes in hand and use them more effectively by re-forming for a more qualified learning" [5]. Metacognition is the ability of developing a strategy to gain the knowledge we need, being conscious of our own steps and strategies during the problem solving period [6]. Metacognition is defined by Gelen [7] as "thinking systematics", "the ability of "learning how to learn" points out the individual's awareness about thinking and learning. Metacognition includes such talents as the individual's estimating, planning, observing and evaluating his/her own mental processes [8]. In other words, metacognition is the individual's capacity of controlling and directing his/ her own metacognitive processes [9]. According to Schunk [10], metacognition is high-level cognition. According to Senemoğlu [11], metacognition is also about noticing and realizing how a person learns in addition to understanding and learning something. Metacognition can shortly be defined as a person's noticing his/her own thinking processes and being able to control these processes $[12,13,14,15,16]$.

There are four components of metacognition; metacognition knowledge, metacognitive experiences, objectives and strategies. Metacognition knowledge is a child or adult's stored knowledge about the world. This 
knowledge is about humans to be seen as the cognitive creatures and refers to the various cognitive duties, objectives, behaviors and experiences of humans. The belief that a child's arithmetical knowledge is better than his/her writing and punctuation knowledge can be given as an example to this. Metacognitive experience is conscious, cognitive or affective experience about any mental activity. The feeling you have suddenly feel when you do not understand what someone has said can be given as an example to this. Objectives (duties) address to the goals of a cognitive activity, and strategies refer to the cognition or to other behaviors applied to gain cognition [12].

Metacognition is related to such subjects as a person's cognitive knowledge processes and memory, attention, knowledge, estimation and mistake. What is significant here is not how a person runs these processes, but is what his/her knowledge and beliefs are about those. The premise at the background of the studies in the metacognitive field is not only how individuals perceive the behaviors, events and aims but also, more importantly, about the fact that they are the organisms who recognize their own cognitions [13]. Metacognition requires asking and replying the following questions [17]:

- What do I know about this subject?

- Do I know what I need in order to know?

- Do I know where I can get some information?

- How much time am I going to need to acquire this knowledge?

- What are some tactics and strategies I can use in learning?

- $\quad$ Did I understand what I saw, heard and read?

- How can I know whether I learned enough or not?

- How can I find out if I do a mistake?

- If my plan does not meet my expectations, how should I revise my plan?

Students having metacognitive skills at a good level are the students who can think critically, solve problems and decide better than the ones who do not have these skills $[18,19,20]$. From this point of view, metacognition is essential for a successful learning because it enables the individuals to direct their own cognitive skills towards a higher level. Metacognition, different from the cognition, it starts with the awareness and increases in accordance with the academic success. The next step is to teach the strategies and more importantly is to help structuring the explicit knowledge about when and where these strategies will be used. As a third step, a flexible strategy repertoire can be used for making careful and regulative decisions that will allow the individuals plan, observe and evaluate their own learning. Metacognitive knowledge and organization can be improved through in-class training applications, and students can use the newly acquired skills to improve their performances as well [21].
Likewise, Flavell [12], Brown et al. [22], Garner \&Alexander [23] and Baer Hollenstein, et al. [24] state that the metacognitive skills can be improved.

Metacognition training can increase students' own personal responsibility perceptions towards their improvement, self-confidence [25], learning motivation and self-efficacy [26, 27, 28]. According to the results of Özsoy and Ataman's research [29], a training program in which metacognitive strategies are applied, develops students' problem solving skills. In Bağçeci, Döş and Sarıca's study [30], a significant positive correlation has been found between the students' metacognitive awareness level and academic success grades. They have been highlighted that the teachers should do more activities to improve the metacognitive awareness. In Özcan's study [31], a positive correlation has been found between the teachers' use of metacognitive skills during their pre-service education and their use of metacognitive skills in their own teaching experiences. All these results show that metacognition is a factor increasing academic success. It is significant for teachers to have a high metacognitive awareness and do applications to develop metacognition in their classrooms. It is important to improve the metacognition levels of the prospective teachers to increase their awareness as well. In the light of this information, the effect of a metacognition-based instructional practice on the metacognitive awareness of the prospective teachers has been explored in this study. For this purpose, answers have been searched for the following questions:

- Does the metacognitive awareness level of the control group increase significantly as a result of the current training?

- Does the metacognitive awareness level of the experimental group increase significantly with a metacognition-based instructional practice?

- Is there a significant difference between metacognitive awareness in pre-test mean scores of the control group and the experimental group?

- Is there a significant difference between metacognitive awareness in post-test mean scores of the control group and the experimental group?

\section{Methods}

A quantitative method has been used in the study. The study has been carried out through the "Pre-test - Post-test Control Group Model" which is of the experimental designs. Also, in the Pre-test - Post-test Control Group Model, two groups are formed through random selection method. In these groups which are called as control and experimental, pre- and post- experiment measurements are carried out [32]. 
Table 1. Metacognitive awareness levels of the Experimental and Control groups

\begin{tabular}{|c|c|c|c|c|c|c|}
\hline & Groups & $\mathrm{n}$ & Mean rank & Sum of ranks & MWU & $\mathrm{p}$ \\
\hline \multirow{2}{*}{ MAS } & Experiment & 22 & 25,6 & 563,5 & \multirow{2}{*}{173,500} & \multirow{2}{*}{0,11} \\
& Control & 22 & 19,4 & 426,5 & \\
\hline
\end{tabular}

\subsection{Study Group}

The study group of the research has been selected from the $3^{\text {rd }}$ year prospective teachers having their education at Department of Turkish Teaching at a State University. In order to identify the prospective teachers to be involved in the experimental and control groups, a cluster analysis has been carried out by taking the grades of the "Teaching Principles and Methods", "Special Teaching Methods" and "Classroom Management" courses as a criterion. According to the result of the cluster analysis, 22 prospective teachers have taken part in the experimental group, and 22 in the control group. Before the experimental application, a "Metacognitive Awareness Scale" (MAS) has been applied to the experimental group and control group, and whether there is statistically a significant difference between the metacognitive awareness levels has been identified by Mann-Whitney U (MWU) test. MWU test results of the experimental and control groups are given at Table 1.

As can be seen from table 1, no statistically significant difference has been found between the experimental group and control group at 0,05 significance level. These results show that the experimental and control groups are equivalent to each other before the experimental application in terms of metacognitive awareness level.

\subsection{Experimental Process}

Experimental Process has been carried out at "Testing and Evaluation in Education" course and lasted for 10 weeks. While a metacognition-based instructional practice has been carried out for the Experimental Group, current training program has been followed for the control group. Within the metacognition-based instructional practice, in-class and out-of-class activities and tasks have been administered. In the metacognition-based instructional practice, the notion of "cognition" which is particularly accepted as a part of metacognition, embedded with metacognition, and expressed as the mental process in which individual's own knowledge about himself/ herself and others is acquired and commented has been selected as the baseline. The tasks towards learning the learning and thinking about the thinking have been included. Individuals are expected to do self-reflections during the metacognitive process with the aim of improving their metacognitive awareness. Therefore, reflective questions towards the prospective teachers' thoughts about their own performances during the teaching period have been included. Planning, observing and evaluating stages of the metacognitive regulation process have been observed during these activities. Participants have been requested to share their experiences prior to, during, and following the tasks that they are required to accomplish. It is aimed that the prospective teachers define, explain, give example, interpret, guess, apply, summarize, argue, contact and inquire. Moreover, a conceptual mapping, which is suggested as a metacognitive skill by Daley [33] has also been included in the process.

\subsection{Data Collection Tool and Data Analysis}

"Metacognitive Awareness Scale" (MAS) developed as a data collection tool by Duman [34] has been used in the study. 31 items are included in the 5 point Likert Type scale. KMO (Kaiser-Mayer-Olkin) value of the scale has been measured as 0,893 and Bartlett test value has been measured as 4539,827 at a significance level of 0,05 . Factor analysis shows that the scale is of 7 factors. The first factor is called as planning (4 items), the second factor as awareness (3 items), the third factor as control (4 items), the fourth factor as regulation (4 items), the fifth factor as questioning (5 items), the sixth factor as motivation ( 2 items), and the seventh factor as evaluation (9 items). Cronbach Alpha reliability coefficients of the factors have respectively been found as 0,70 for the first, 0,71 for the second, 0,67 for the third, 0,61 for the fourth, 0,67 for the fifth, 0,54 for the sixth, and 0,80 for the seventh factor. The total reliability co-efficient of the scale has been calculated as 0,89 . "Wilcoxon Signed Two Rank Tests" were used for the dependent groups because the data was not normally distributed, and "Mann-Whitney U Test" was used for the independent groups. For the data analysis, SPSS 20 package was used.

\section{Findings}

Findings of the study have been revealed in accordance with the research questions respectively. In order to direct the question "Does the metacognitive awareness level of the control group increase significantly as a result of the current training?", "Wilcoxon Signed Two Rank Tests" were applied (Table 2). 
Table 2. Test Results of the Wilcoxon Signed Two Rank Tests of the Control Group Metacognitive Awareness Scale

\begin{tabular}{|c|c|c|c|c|c|c|}
\hline Sub-dimensions & Post-test Pre-test & $\mathrm{n}$ & Mean rank & Sum of ranks & Z & $\mathrm{p}$ \\
\hline \multirow{3}{*}{ Planning } & Negative Ranks & 6 & \multirow{3}{*}{$\begin{array}{l}9,17 \\
8,10\end{array}$} & \multirow{3}{*}{$\begin{array}{l}55,00 \\
81,00\end{array}$} & \multirow{3}{*}{$-0,679^{b}$} & \multirow{3}{*}{0,497} \\
\hline & Positive Ranks & 10 & & & & \\
\hline & Ties & 6 & & & & \\
\hline \multirow{3}{*}{ Awareness } & Negative Ranks & 9 & \multirow{3}{*}{$\begin{array}{l}10,50 \\
10,50\end{array}$} & \multirow{3}{*}{$\begin{array}{c}94,50 \\
115,50\end{array}$} & \multirow{3}{*}{$-0,396^{\mathrm{b}}$} & \multirow{3}{*}{0,692} \\
\hline & Positive Ranks & 11 & & & & \\
\hline & Ties & 2 & & & & \\
\hline \multirow{3}{*}{ Control } & Negative Ranks & 8 & \multirow{3}{*}{$\begin{array}{c}8,81 \\
10,86\end{array}$} & \multirow{3}{*}{$\begin{array}{c}70,50 \\
119,50\end{array}$} & \multirow{3}{*}{$-0,991^{\mathrm{b}}$} & \multirow{3}{*}{0,322} \\
\hline & Positive Ranks & 11 & & & & \\
\hline & Ties & 3 & & & & \\
\hline \multirow{3}{*}{ Regulation } & Negative Ranks & 12 & \multirow{3}{*}{$\begin{array}{c}8,38 \\
11,75\end{array}$} & \multirow{3}{*}{$\begin{array}{c}100,50 \\
70,50\end{array}$} & \multirow{3}{*}{$-0,657^{\mathrm{a}}$} & \multirow{3}{*}{0,511} \\
\hline & Positive Ranks & 6 & & & & \\
\hline & Ties & 4 & & & & \\
\hline \multirow{3}{*}{ Questioning } & Negative Ranks & 5 & \multirow{3}{*}{$\begin{array}{c}9,20 \\
10,93\end{array}$} & \multirow{3}{*}{$\begin{array}{c}46,00 \\
164,00\end{array}$} & \multirow{3}{*}{$-2,230^{\mathrm{b}}$} & \multirow{3}{*}{$0,026^{*}$} \\
\hline & Positive Ranks & 15 & & & & \\
\hline & Ties & 2 & & & & \\
\hline \multirow{3}{*}{ Motivation } & Negative Ranks & 6 & \multirow{3}{*}{$\begin{array}{c}11,50 \\
9,31\end{array}$} & \multirow{3}{*}{$\begin{array}{c}69,00 \\
121,00\end{array}$} & \multirow{3}{*}{$-1,064^{\mathrm{b}}$} & \multirow{3}{*}{0,288} \\
\hline & Positive Ranks & 13 & & & & \\
\hline & Ties & 3 & & & & \\
\hline \multirow{3}{*}{ Evaluation } & Negative Ranks & 8 & \multirow{3}{*}{$\begin{array}{l}10,13 \\
10,75\end{array}$} & \multirow{3}{*}{$\begin{array}{c}81,00 \\
129,00\end{array}$} & & \\
\hline & Positive Ranks & 12 & & & $-0,898^{\mathrm{b}}$ & 0,369 \\
\hline & Ties & 2 & & & & \\
\hline & Negative Ranks & 8 & & & & \\
\hline Scale-wide & Positive Ranks & 14 & $\begin{array}{l}10,31 \\
12,18\end{array}$ & $\begin{array}{c}82,50 \\
170,50\end{array}$ & $-1,431^{\mathrm{b}}$ & 0,152 \\
\hline & Ties & 0 & & & & \\
\hline
\end{tabular}

${ }^{*} \mathrm{p}<.05,{ }^{\mathrm{b}}:$ Based on negative ranks

As can be observed from Table 2, there is a significant difference between the pre-test and post-test scores related to the "questioning" sub-dimension of the control group $(\mathrm{Z}=-2,230, \mathrm{p}<.05)$. When mean rank and total difference scores are taken into account, it can be stated that the observed difference is at the negative ranks. In other words, it is in favor of the post test scores. In the other sub-dimensions and the scale in general, there is no significant difference observed. It can be interpreted that these results do not have an important effect at the scale in general and the other sub-dimensions except the questioning sub-dimension of the control group.

In order to answer the question "Does the metacognitive awareness level of the experimental group increase significantly with a metacognition-based instructional practice?, a Wilcoxon Signed Two Rank Tests has been applied (Table 3).

According to the results presented in Table 3, there is a significant difference between the pre-test and post-test scores in "planning" $(\mathrm{Z}=-2,431 \mathrm{p}<.05)$, "awareness" $(\mathrm{Z}=-2,656 \mathrm{p}<.05)$ and "questioning" $(\mathrm{Z}=-2,686 \mathrm{p}<.05)$ sub-dimensions of the experimental group. In the other sub-dimensions and the scale in general, there is no significant difference. When mean rank and total of the difference scores are taken into account, it is seen that the observed difference is at the negative ranks. In other words, it is in favor of the post-test points. These results can be interpreted as a metacognition-based instructional practice is effective on improving the metacognitive awareness at the "planning", awareness" and "questioning" sub-dimensions.

In order to address the question "Is there a significant difference between metacognitive awareness in pre-test mean scores of the control group and the experimental group?", a "Mann-Whitney U Test" has been carried out (Table 4).

The results of analysis in Table 4 show that there is no significant difference between the pre-test mean scores of the experimental group and control group before the experimental process is carried out. This result can be interpreted as the experimental and control groups are not significantly different from each other before the experimental study in terms of metacognitive awareness. 
Table 3. Test Results of the Wilcoxon Signed Two Rank Tests of the Experimental Group Metacognitive Awareness Scale

\begin{tabular}{|c|c|c|c|c|c|c|}
\hline Sub-dimensions & Post-test Pre-test & $\mathrm{n}$ & Mean rank & Sum of ranks & Z & $\mathrm{p}$ \\
\hline \multirow{3}{*}{ Planning } & Negative Ranks & 5 & \multirow{3}{*}{$\begin{array}{c}8,10 \\
11,30\end{array}$} & \multirow{3}{*}{$\begin{array}{c}40,50 \\
169,50\end{array}$} & \multirow{3}{*}{$-2,431^{\mathrm{b}}$} & \multirow{3}{*}{$0,015^{*}$} \\
\hline & Positive Ranks & 15 & & & & \\
\hline & Ties & 2 & & & & \\
\hline \multirow{3}{*}{ Awareness } & Negative Ranks & 3 & \multirow{3}{*}{$\begin{array}{l}7,00 \\
9,43\end{array}$} & \multirow{3}{*}{$\begin{array}{c}21,00 \\
132,00\end{array}$} & \multirow{3}{*}{$-2,656^{\mathrm{b}}$} & \multirow{3}{*}{$0,008^{*}$} \\
\hline & Positive Ranks & 14 & & & & \\
\hline & Ties & 5 & & & & \\
\hline \multirow{3}{*}{ Control } & Negative Ranks & 7 & \multirow{3}{*}{$\begin{array}{l}8,57 \\
7,50\end{array}$} & \multirow{3}{*}{$\begin{array}{l}60,00 \\
60,00\end{array}$} & \multirow{3}{*}{$0,000^{\mathrm{c}}$} & \multirow{3}{*}{1,000} \\
\hline & Positive Ranks & 8 & & & & \\
\hline & Ties & 7 & & & & \\
\hline \multirow{3}{*}{ Regulation } & Negative Ranks & 9 & \multirow{3}{*}{$\begin{array}{l}8,67 \\
8,29\end{array}$} & \multirow{3}{*}{$\begin{array}{l}78,00 \\
58,00\end{array}$} & \multirow{3}{*}{$-0,525^{\mathrm{a}}$} & \multirow{3}{*}{0,599} \\
\hline & Positive Ranks & 7 & & & & \\
\hline & Ties & 6 & & & & \\
\hline \multirow{3}{*}{ Questioning } & Negative Ranks & 4 & \multirow{3}{*}{$\begin{array}{c}5,00 \\
10,23\end{array}$} & \multirow{3}{*}{$\begin{array}{c}20,00 \\
133,00\end{array}$} & \multirow{3}{*}{$-2,686^{\mathrm{b}}$} & \multirow{3}{*}{$0,007^{*}$} \\
\hline & Positive Ranks & 13 & & & & \\
\hline & Ties & 5 & & & & \\
\hline \multirow{3}{*}{ Motivation } & Negative Ranks & 11 & \multirow{3}{*}{$\begin{array}{l}9,64 \\
9,29\end{array}$} & \multirow{3}{*}{$\begin{array}{c}106,00 \\
65,00\end{array}$} & \multirow{3}{*}{$-0,926^{\mathrm{a}}$} & \multirow{3}{*}{0,355} \\
\hline & Positive Ranks & 7 & & & & \\
\hline & Ties & 4 & & & & \\
\hline \multirow{3}{*}{ Evaluation } & Negative Ranks & 7 & \multirow{3}{*}{$\begin{array}{c}12,00 \\
8,83\end{array}$} & \multirow{3}{*}{$\begin{array}{c}84,00 \\
106,00\end{array}$} & & \\
\hline & Positive Ranks & 12 & & & $-0,444^{\mathrm{b}}$ & 0,657 \\
\hline & Ties & 3 & & & & \\
\hline & Negative Ranks & 6 & & & & \\
\hline Scale-wide & Positive Ranks & 15 & $\begin{array}{l}11,08 \\
10,97\end{array}$ & $\begin{array}{c}66,50 \\
164,50\end{array}$ & $-1,704^{b}$ & 0,088 \\
\hline & Ties & 1 & & & & \\
\hline
\end{tabular}

$* \mathrm{p}<.05$, b: Based on negative ranks

Table 4. Test Results of the Mann-Whitney U Test of the Experimental and Control Groups Metacognitive Awareness Scale Pre-Test Point Averages

\begin{tabular}{|c|c|c|c|c|c|c|}
\hline Sub-dimensions & Groups (pre-test) & $\mathrm{n}$ & Mean rank & Sum of ranks & MWU & $\mathrm{p}$ \\
\hline \multirow{2}{*}{ Planning } & Experiment & 22 & \multirow{2}{*}{$\begin{array}{l}26,02 \\
18,98\end{array}$} & \multirow{2}{*}{$\begin{array}{l}572,50 \\
417,50\end{array}$} & \multirow{2}{*}{164,500} & \multirow{2}{*}{0,067} \\
\hline & Control & 22 & & & & \\
\hline \multirow{2}{*}{ Awareness } & Experiment & 22 & \multirow{2}{*}{$\begin{array}{l}24,18 \\
20,82\end{array}$} & \multirow{2}{*}{$\begin{array}{l}532,00 \\
458,00\end{array}$} & \multirow{2}{*}{205,000} & \multirow{2}{*}{0,380} \\
\hline & Control & 22 & & & & \\
\hline \multirow{2}{*}{ Control } & Experiment & 22 & \multirow{2}{*}{$\begin{array}{l}23,32 \\
21,68\end{array}$} & \multirow{2}{*}{$\begin{array}{l}513,00 \\
477,00\end{array}$} & \multirow{2}{*}{224,000} & \multirow{2}{*}{0,670} \\
\hline & Control & 22 & & & & \\
\hline \multirow{2}{*}{ Regulation } & Experiment & 22 & \multirow{2}{*}{$\begin{array}{l}24,93 \\
20,07\end{array}$} & \multirow{2}{*}{$\begin{array}{l}548,50 \\
441,50\end{array}$} & \multirow{2}{*}{188,500} & \multirow{2}{*}{0,202} \\
\hline & Control & 22 & & & & \\
\hline \multirow{2}{*}{ Questioning } & Experiment & 22 & \multirow{2}{*}{$\begin{array}{l}25,20 \\
19,80\end{array}$} & \multirow{2}{*}{$\begin{array}{l}554,50 \\
435,50\end{array}$} & \multirow{2}{*}{182,500} & \multirow{2}{*}{0,160} \\
\hline & Control & 22 & & & & \\
\hline \multirow{2}{*}{ Motivation } & Experiment & 22 & \multirow{2}{*}{$\begin{array}{l}25,07 \\
19,93\end{array}$} & \multirow{2}{*}{$\begin{array}{l}551,50 \\
438,50\end{array}$} & \multirow{2}{*}{185,500} & \multirow{2}{*}{0,171} \\
\hline & Control & 22 & & & & \\
\hline \multirow{2}{*}{ Evaluation } & Experiment & 22 & \multirow{2}{*}{$\begin{array}{l}25,07 \\
19,93\end{array}$} & \multirow{2}{*}{$\begin{array}{l}551,50 \\
438,50\end{array}$} & \multirow{2}{*}{185,00} & \multirow{2}{*}{0,183} \\
\hline & Control & 22 & & & & \\
\hline \multirow{2}{*}{ Scale-Wide } & Experiment & 22 & \multirow{2}{*}{$\begin{array}{l}25,61 \\
19,39\end{array}$} & 563,50 & 1600 & 0108 \\
\hline & Control & 22 & & 426,50 & $-1,009$ & 0,100 \\
\hline
\end{tabular}


Table 5. Test Results of the Mann-Whitney U Test of the Experimental and Control Groups Metacognitive Awareness Scale Post-Test Point Averages

\begin{tabular}{|c|c|c|c|c|c|c|}
\hline Sub-dimensions & Groups (post-test) & $\mathrm{n}$ & Mean rank & Sum of ranks & MWU & $\mathrm{p}$ \\
\hline \multirow{2}{*}{ Planning } & Experiment & 22 & 27,98 & 615,50 & \multirow{2}{*}{121,500} & \multirow{2}{*}{$0,004 *$} \\
\hline & Control & 22 & 17,02 & 374,50 & & \\
\hline \multirow{2}{*}{ Awareness } & Experiment & 22 & 30,32 & 667,00 & \multirow{2}{*}{70,000} & \multirow{2}{*}{$0,000^{*}$} \\
\hline & Control & 22 & 14,68 & 323,00 & & \\
\hline \multirow{2}{*}{ Control } & Experiment & 22 & 21,20 & 466,50 & \multirow{2}{*}{213,500} & \multirow{2}{*}{0,496} \\
\hline & Control & 22 & 23,80 & 523,50 & & \\
\hline \multirow{2}{*}{ Regulation } & Experiment & 22 & 27,57 & 606,50 & \multirow{2}{*}{130,500} & \multirow{2}{*}{$0,007^{*}$} \\
\hline & Control & 22 & 17,43 & 383,50 & & \\
\hline \multirow{2}{*}{ Questioning } & Experiment & 22 & 28,23 & 633,00 & \multirow{2}{*}{104,000} & \multirow{2}{*}{$0,001 *$} \\
\hline & Control & 22 & 16,23 & 357,00 & & \\
\hline \multirow{2}{*}{ Motivation } & Experiment & 22 & 21,59 & 475,00 & \multirow{2}{*}{222,000} & \multirow{2}{*}{0,619} \\
\hline & Control & 22 & 23,41 & 515,00 & & \\
\hline \multirow{2}{*}{ Evaluation } & Experiment & 22 & 23,59 & 519,00 & \multirow{2}{*}{218,000} & \multirow{2}{*}{0,571} \\
\hline & Control & 22 & 21,41 & 471,00 & & \\
\hline \multirow{2}{*}{ Scale-Wide } & Experiment & 22 & 26,89 & 591,50 & \multirow{2}{*}{145,500} & \multirow{2}{*}{$0,023^{*}$} \\
\hline & Control & 22 & 18,11 & 398,50 & & \\
\hline
\end{tabular}

$* \mathrm{p}<.05$

In order to reply the question "Is there a significant difference between metacognitive awareness in post-test mean scores of the control group and the experimental group?", a "Mann-Whitney U Test" has been performed (Table 5).

As it can be seen from the analysis presented in Table 5, there is a significant difference between the post-test scores of the prospective teachers in the experimental and control groups in "planning" (MWU $=121,500 \mathrm{p}<.05)$, "awareness" (MWU=70,000 p<.05), "regulation" (MWU= $130,500 \mathrm{p}<.05)$ and "questioning" (MWU=104,000 p<.05) sub-dimensions, and at the scale in general (MWU=145,500 $\mathrm{p}<.05$ ). In the other sub-dimensions, there is no significant difference between two groups. When mean rank and total scores are taken into account, it can be stated that the observed difference is in favor of the experimental group. All in all, these results can be interpreted as metacognition-based instructional practice is more effective than the current teaching on improving the metacognitive awareness of the prospective teachers in the "planning", "awareness", "regulation" and "questioning" sub-dimensions.

\section{Conclusions}

Metacognition is a person's planning, observation of, arranging, controlling over, directing, evaluating and reflecting on his/her own cognitive processes and so, it is his/her noticing about how he/she thinks and learns. Various studies carried out by Flavell [12], Brown et al. [22], Garner and Alexander [23] and Bear Hollenstein et al.
[24] have shown that metacognitive skills can be developed, and that the students can learn better in this way. Studies have been conducted on adults by Flavell [35]; Glenberg, Wilkinson and Epstein [36] and Garner and Alexander [23]. In these studies, it has been identified that the adults fail especially in observing their thinking. Yet, it is claimed that they can improve their metacognition skills through training.

The idea that metacognition includes one's noticing how she/he thinks and learns shows that active thinking process can be fostered by metacognition. Therefore, the effect of a metacognition-based instructional practice on the metacognitive awareness of the prospective teachers has been studied in this study. From this aspect, that the teachers' performing applications based on metacognition while they are still prospective teachers will be useful both in terms of the improvement of their own learning process and their students'.

According to the results of the study, there is a significant increase at the end of the experimental process in favor of the post-test in the "questioning" level of the control group at which the current training program is applied, but it has been discovered that the metacognitive awareness did not improve at the sub-dimension and in general.

When pre- and post-test results of the experimental group at which a metacognition-based instructional practice is applied are examined, significant increases have been observed in the "planning", awareness", and "questioning" sub-dimensions in favor of the post-test. These increases show that the metacognition-based instructional practice has affected the metacognitive 
awareness on such subjects as time planning, setting an objective and planning the steps to be followed. It can be stated that the metacognition-based instructional practice has improved the metacognitive awareness devoted to the questioning such as asking himself/ herself questions, explaining the information in his/ her own words and searching in detail whatever he/ she did not understand while learning. Besides, it can also be stated that this teaching is effective on realizing the learning strategies and acquiring the awareness of how one will learn better. In the same vein, it has been found out that the metacognition-oriented teaching applications have improved the metacognitive skills in various studies $[1,37$, $38,39,40]$. Likewise, metacognitive activity and strategies' increasing the metacognitive awareness has been discovered in the study carried out by Aydemir and Karaman [41] with the students receiving distance education.

The results of the experimental group at the other low-dimensions and scale in general have shown that the metacognitive awareness did not change significantly. However it has been already stated before that improving the metacognitive skills of the adults takes time [23]. No increase at every dimension may result from the time made for the experimental process. Similarly, Weissbein [42] emphasizes that the metacognition should be planned together with the teaching program and extended over a long period of time.

When the post-test results of the experimental and control groups are examined, significant differences have been observed in favor of the experimental group. These results show that the metacognition-based instructional practice is generally more effective than the current training in terms of increasing metacognitive awareness and planning, awareness, regulation and questioning sub-dimensions related to the metacognitive awareness. Metacognition-based instructional practice has become more effective than the current training on such subjects as making a plan before starting work, noticing the learning strategies, arranging the pace of studying according to the situation and conditions, thinking about how to be successful, considering the alternatives in solving the problems and searching in detail when he/she did not understand. In Arslan and Gelişli's study [43], it has been concluded that the self-regulation levels of the students realised at the end of the applications- at the experimental group at which metacognitive teaching strategies are used have increased. In a study carried out by Yurdakul and Demirel [44], it has been discovered that the traditional teaching is inadequate in improving the metacognitive awareness. In a study conducted with the students of the faculty of medicine by Gönül and Artar [45], it has been revealed that metacognitive awareness can be improved through education. In the study carried out by Özcan [31], it has been discovered that there is a positive correlation between the teachers' use of metacognitive skills during their education and their use of metacognitive skills in their own teachings. It has also been found out that there are correlations between the universities that teachers graduated from and their use of the metacognitive skills in their teachings. According to these results, it can be expressed that the training the teachers got while they were prospective teachers has affected their metacognitive skills. Therefore, it is thought that a teaching based on improving the metacognitive skills will be useful for training the teachers at the faculties of education.

In the study, it has been concluded that the metacognition-based instructional practice has positively affected the metacognitive awareness of the prospective teachers. It is suggested that the applications based on metacognition should be carried out at the faculties of education by means of including all departments and levels.

This study has lasted for ten weeks. Therefore, it will be beneficial to observe the improvement of the prospective teachers through longer-term experimental researches.

In the studies to be done hereafter, richer data can be acquired by using both qualitative and quantitative together as research methods.

\section{REFERENCES}

[1] A. Çakıroğlu, The effect of metacognitive strategy training on improving the achievement level of students having low achievement levels of reading comprehension. Unpublished Ph thesis, Gazi University, Institute of Educational Sciences, Ankara, 2007.

[2] P. Douville, G. D. Pugalee. Investigating the Relationship between Mental Imaging and Mathematical Problem Solving. The Mathematics Education into the 21st Century Project. Proceedings of the International Conference the Decidable and the Undecidable in Mathematics Education Brno, Czech Republic, September, 2003.

[3] P. Georghiades. From the general to the situated: Three decades of metacognition. International Journal of Science Education, Vol.26, No.3, 365-383, 2004.

[4] D. Hacker. Definitions and Empirical Foundations. D Hacker, J. Dunlosky, A. Gracsser (Ed) Metacogniton: Educational Theory and Practice, Erlbaum, London. 1998.

[5] G. Ülgen. Eğitim Psikolojisi. Alkım Yayınevi, Ankara, 1997.

[6] A. L. Costa. Mediating the Metacognitive, Educational Leadership, Vol.42, No.3, 57-62, 1984.

[7] İ. Gelen. Bilişsel Farkındalık Stratejilerinin Türkçe Dersine İlişkin Tutum, Okuduğunu Anlama ve Kalıcılığa Etkisi. XIII. Ulusal Eğitim Bilimleri Kurultayı, 6-9 Temmuz 2004 İnönü Üniversitesi, Eğitim Fakültesi, Malatya, 2004.

[8] A. L. Brown. Metacognitive Development and Reading. R. J. Spiro, B. Bruce and W. Brewer (Ed) Theoretical Issues in Reading Comprehension. Hillslade, NJ: Lawrence Erbaum, 
1980.

[9] R. A. Reeve, A. L. Brown. Metacognition Reconsidered: Implications for Intervention Research. Journal of Abnormal Child Psychology, Vol.13, No.3, 343-356, 1985.

[10] D. H. Schunk. Öğrenme Teorileri Eğitimsel Bir Bakışla (Çev. M. Şahin). Nobel Yayın Dağıtım, Ankara, 2009.

[11] N. Senemoğlu. Gelişim Öğrenme ve Öğretim (12. Basım). Gazi Kitabevi, Ankara, 2005.

[12] J. Flavell. Metacognition and Cognitive Monitoring: A New Area of Cognitive-Developmental Inquiry. American Psychologist, Vol.34, No.10, 906-911, 1979.

[13] H. M. Wellman. The Origins of Metacognition. D. L. Forrest-Pressley, G.E. MacKinnon and T. Garry Waller (Ed) Metacognition, Cognition, and Human Performance Vol. 1 Theoretical Perspectives. Academic Press INC, Orlando, Florida, 1985.

[14] D. J. Hacker, J. Dunlosky. Not All Metacognition is Created Equal. New Directions for Teaching and Learning, Vol.95, 73-79, 2003.

[15] B. Jager, M. Jansen, G. Reezigt. The Development of Metacognition in Primary School Learning Environments. School Effectiveness and School Improvement, Vol.16, No.2, 179-196, 2005.

[16] L. Baker. Metacognition. International Encyclopedia of Education (Third Edition), 204-210, 2010.

[17] W. Huitt. Metacognition. Educational Psychology Interactive. Valdosta, GA: Valdosta State University, 1997. http://www.edpsycinteractive.org/topics/cogsys/metacogn.h tml.

[18] S. B. Heath. Ways with Words: Language, Life, And Work in Communities And Classrooms. Cambridge University Press, Cambridge, MA, 1983.

[19] J. D. Bransford, R. Sherwood, N. J. Vye, J. Rieser. Teaching Thinking and Problem Solving. American Psychologist, Vol.41, No.10, 1078-1089, 1986.

[20] A. Ewell-Kumar. The Influence of Metacognition on Managerial Hiring Decision Making: Implications for Management Development. Dissertation Abstracts International Section A: Humanities and Social Sciences, Vol.59, No.10-A, 1999.

[21] G. Schraw. Promoting General Metacognitive Awareness. Instructional Science, Vol.26, 113-125, 1998.

[22] A. L. Brown, J. D. Bransford, R. A. Ferrara, J. C. Campione. Learning, Remembering, and Understanding. In J. H. Flavell and E. M. Markman (Eds.), Carmichael's Manual of Child Psychology, Vol. 1, 77-166, New York: Wiley, 1983.

[23] R. Garner, P. A. Alexander. Metacognition: Answered and Unanswered Questions. Educational Psychologist, Vol.24, No.2, 143-158, 1989.

[24] M. Baer, A. Hollenstein, M. Hofstetter, M. Fuchs, M. Reber-Wyss. How D Expert and Novice Writers Differ in Their Knowledge of The Writing Process and Its Regulation (Metacognition) From Each Other, and What Are The Differences in Metacognitive Knowledge Between Writers of Different Ages? Paper Presented at The Annual Meeting of The American Educational Research Association, 1994.

[25] D.H. Schunk. Goal Setting and Self-Efficacy during Self-Regulated Learning. Educational Psychologist, Vol.25, 71-86, 1990

[26] A. Bandura. Social Foundations of Thought and Action: A Social Cognitive Theory. Prentice-Hall, Englewood Cliffs, NJ., 1986.

[27] B. K. Hofer, S. L. Yu. Teaching Self-Regulated Learning through A "Learning To Learn" Course. Teaching in Psychology, Vol.30, No.1, 30-33, 2003.

[28] R.A. Sperling, B.C. Howard, R. Staley, N. DuBois. Metacognition and Self-Regulated Learning Constructs. Educational Research and Evaluation, Vol.10, No.2, 117-139, 2004.

[29] G. Özsoy, A. Ataman. The Effect of Metacognitive Strategy Training on Mathematical Problem Solving Achievement. International Electronic Journal of Elementary Education, Vol.1, No. 2, 68-83, 2009.

[30] B. Bağçeci, B. Döş, R. An Analysis of Metacognitive Awareness Levels and Academic Achievement of Primary School Students. Mustafa Kemal University Journal of Social Sciences Institute, Vol.8, No.16, 551-566, 2011.

[31] Z. Ç. Özcan. Investigation of Primary School Teachers Use of Metacognitive Strategies in Their Lessons. Unpublished $\mathrm{Ph}$ thesis, Marmara University, Institute of Educational Sciences, İstanbul, 2007.

[32] N. Karasar. Bilimsel Araştırma Yöntemi. Nobel Yayın Dağıtım, Ankara, 2006.

[33] B .J. Daley. Facilitating Learning with Adult Students through Concept Mapping. Journal of Continuing Higher Education, Vol.50, No.1, 21-32, 2002.

[34] B. Duman. The Effect of An Instructional Practice Based On Metacognition Upon Teacher Trainees Academic Achievement, Metacognitive Awareness, Achievement Motivation And Critical Thinking. Unpublished Ph thesis, Firat University, Institute of Educational Sciences, Elazığ 2013.

[35] J. H. Flavell. Cognitive Monitoring. In W. P. Dickson (Ed.) Children's Oral Communication Skills (35-60). Academic, New York, 1981.

[36] A. M. Glenberg, A. C. Wilkinson, W. Epstein. The Illusion of Knowing: Failure in the Self-Assessment of Comprehension. Memory and Cognition, Vol.10, 597-602, 1982.

[37] S. Muhtar. Effects of Training University EFL Students in Metacognitive Strategies for Reading. Unpublished Master thesis, Ankara University, Institute of Social Sciences, Ankara, 2006.

[38] H. Demircioğlu. Effectiveness of Educational Events Designed for The Development Of Metacognitive Behaviours of Prospective Mathematics Teachers. Unpublished $\mathrm{Ph}$ thesis, Gazi University, Institute of Educational Sciences, Ankara, 2008.

[39] B. Çakır. Pre-Service Science Teachers' Metacognition in A Science Laboratory Course With Metacognitively Oriented Learning Environment. The Degree Of Master Of Science, 
Middle East Technical University Department of Elementary Science and Mathematics Education, Ankara, 2011.

[40] Ö. Esendemir. A Model of Professional Development Program on Mathematical Problem Solving and Metacognition and Effectiveness of This Program. Unpublished Master thesis, Gaziantep University, Institute of Social Sciences, Gaziantep, 2011.

[41] M. Aydemir, S. Karaman. An Investigation of Metacognitive Activities in Terms of Distance Education Students' Study Process and Metacognitive Level. Educational Technology Theory and Practice, Vol.7, No.2, 18-40, 2017.

[42] D. A. Weissbein. The Effects of Goal Type and Metacognitive Training on Complex Skill Acquisition: Implications of The Limited Resources Model. Master Thesis, Michigan State University, 1996.

[43] S. Arslan, Y. Gelissli. The Effects of Metacognitive Teaching Strategies on Students' Self-Regulation Skills. FSM Scholarly Studies Journal of Humanities and Social Sciences, Vol.10, 49-60, 2017.

[44] 43. B. Yurdakul, Ö. Demirel. Contributions of Constructivist Learning Approach to Learners' Metacognitive Awareness. International Journal of Curriculum and Instructional Studies (IJOCIS), Vol.1, No.1, 71-85, 2011.

[45] İ. Gönüllü, M. Artar. The Impact of Metacognition training on Metacognitive Awareness of Medical Students. Journal of Theory and Practice in Education, Vol.10, No.2, 594-612, 2014.

${ }^{i}$ NOTE: This research was produced from the first author's doctoral thesis. 